МИХЕЕВ Валентин Александрович - доктор исторических наук, академик РАЕН; профессор Российской академии народного хозяйства и государственной службы при Президенте РФ (119571, Россия, г. Москва, пр-кт Вернадского, 82; mikheеvvа37@ mail.ru)

\title{
ПРИРОДА И ПРАКТИКА РАЗВИТИЯ МЕЖНАЦИОНАЛЬНОГО СОГЛАСИЯ
}

Аннотация. В статье рассматривается научный труд коллектива ученых Федерального научно-исследовательского социологического центра РАН, выполненный под руководством выдающегося отечественного социолога Леокадии Михайловны Дробижевой. В монографии дается анализ формирования и укрепления межнационального согласия, процесса развития российской нации, общероссийской и общегражданской идентичности, культуры, консолидации российского общества.

Ключевые слова: межнациональное согласие, языковое взаимодействие, российская нация, российская и гражданская идентичность, консолидация

И здание крупной научной монографии о межнациональном согласии «Межнациональное согласие в общероссийском и региональном измерении. Социокультурный и религиозный контексты» стало заметным событием в научной и общественно-политической жизни нашей страны [Межнациональное согласие.... 2018]. Монография выполнена коллективом ученых Федерального научно-исследовательского социологического центра РАН под руководством известного видного ученого, доктора социологических наук Леокадии Михайловны Дробижевой.

Монография посвящена межнациональному согласию в общероссийском и региональном измерении как выражению фундаментальной природы цивилизованного общества, основы единства народа, самобытности этнического, культурного, конфессионального многообразия, «ресурса консолидации российского общества» [Межнациональное согласие... 2018: 10]. Укрепление межнационального согласия определено как один из стратегических приоритетов Стратегии государственной национальной политики Российской Федерации на период до 2025 года 1 .

В монографическом исследовании обстоятельно анализируются основные теоретические подходы, методы изучения и выявления роли интеграционных процессов в формировании и укреплении межнационального согласия, в характеристике сущности понятий «российская нация», «общероссийская и общегражданская идентичность», «культура гражданской активности» и др.

Именно об отношениях между людьми и этническими группами, о достижении ими общественного согласия, слаженности в восприятии текущих реалий и событий как внутри, так и вне России представителями разных социокультурных слоев общества и идет речь в данной монографии.

\footnotetext{
1 Указ Президента РФ от 06.12.2018 № 703 «О внесении изменений в Стратегию государственной национальной политики Российской Федерации на период до 2025 года, утвержденную Указом Президента РФ от 19 декабря 2012 года № 1666». Доступ: https://www.garant.ru/products/ipo/prime/ doc/72020010/ (проверено 11.05.2019).
} 
Масштабность, оригинальность, глубина и смелость авторского мышления проявились в определении сущности понятия «межнациональное согласие»1.

В представленное в монографии содержание термина «межнациональное согласие» включаются доброжелательность межэтнических отношений на личном и институциональном уровнях, готовность взаимодействовать с людьми иной культуры в деловой и неформальной сферах, регулировать противоречия в диалоговой форме, межличностное и межгрупповое доверие, согласованные ценностные ориентации, способность людей жить и взаимодействовать на основе доминирующего доверия, равноправия и справедливости.

Все названные дефиниции как ключевые составляющие межнационального согласия обстоятельно и глубоко анализируются авторами в представленной монографии в разнообразных проявлениях.

К примеру, доброжелательность как креативный признак качества межэтнических отношений на личностном и институциональном уровнях воспринимается подавляющим большинством (79\%) однозначно позитивно. При этом межэтнические отношения как доброжелательные и спокойные характеризуют от $66 \%$ до 74\% опрошенных, как имеющие внутреннюю напряженность - 16\%, «на грани открытых столкновений» - $1 \%$ опрошенных [Межнациональное согласие... 2018: 29, 281].

В течение истекших 5 лет проведения исследования готовность взаимодействовать с людьми другой культуры в деловой и неформальной сферах, желание регулировать противоречия в диалоговой форме 80-97\% респондентов воспринимают как «уважение людей независимо от национальности»; 75\% и более - как «признание права людей других национальностей на свой образ жизни» [Межнациональное согласие... 2018: 503].

Масштабно и убедительно исследуется недостаточно проработанная в российских реалиях проблема доверия в контексте межличностного и межгруппового согласия. В монографии представлен тщательный анализ нескольких видов доверия - базового, обобщенного, межэтнического, межконфессионального, культуры доверия во взаимосвязи с проявлениями гражданской и религиозной идентичности. Исследование выполнено с опорой на богатый эмпирический материал.

Базовое доверие рассматривается как степень развития доверия к людям и миру, стремление к этнокультурной «самотождественности», самооценке в координации деятельности, поддержка чувства уверенности и безопасности, проявление уважения к власти - государственной и церковной [Межнациональное согласие... 2018: 266]. Около половины россиян (от $42 \%$ до 47\%) считают, что людям в целом можно доверять, высокое доверие выражают друзьям, семье (90\%) и невысокое - судьям (25-30\%).

Обобщенное доверие (к людям вообще) является универсальным показателем социального благополучия и отражает готовность общества к формированию стабильных гражданских ассоциаций. Исследование обобщенного доверия выявило важную особенность: среди людей с интенсивной религиозной идентичностью доверие правительству вырастает до 66\% (среди не ощущающих связей с единоверцами - 37\%), доверие представителям региональной вла-

1 В монографии межнациональное (межэтническое) согласие характеризуется как «благоприятные, доброжелательные межэтнические отношения на личностном и институциональном уровне, как готовность взаимодействовать с людьми иной культуры в деловой и неформальной сферах общения, регулировать противоречия в диалоговой форме. Это также межличностное и межгрупповое доверие, согласованные ценностные ориентации, способность людей жить в сложном, дифференцированном мире, слышать друг друга и взаимодействовать на основе доминирующего доверия, равноправия и справедливости» [Межнациональное согласие... 2018: 9]. 
сти - до 54\%, местной власти - до $40 \%$ (среди не ощущающих связи - 23\%) [Межнациональное согласие... 2018: 272].

Уровень межконфессионального и межэтнического доверия характеризуется более высоким показателями, чем уровень обобщенного доверия. Так, например, православным в Башкортостане доверяют 73\% представителей башкир, $71 \%$ татар и $76 \%$ русских; мусульманам доверяют 78\% башкир, 71\% татар и 76\% русских. Доверие людям других национальностей также высоко и составляет 62\% у башкир, 59\% у татар, 62\% у русских [Межнациональное согласие... 2018: 284].

Доверие и религиозность, подчеркивается в монографии, можно рассматривать в качестве основ социальной солидарности. Обобщенное и межличностное доверие обеспечивает продуктивность коммуникации, доверие к власти обеспечивает вертикальную консолидацию общества, а религиозность поддерживает моральный консенсус [Межнациональное согласие... 2018: 315]. Традиционные религии России стали для людей «своими» и инициативно включаются в становление наций и этносов во всех республиках, в поиск общероссийской идентичности. Данное исследование, подчеркивают авторы, дает основание утверждать, что религиозность сегодня в известной мере выполняет утраченные государством и пока не сформированные гражданским обществом функции общественной консолидации в формировании межэтнической толерантности [Межнациональное согласие... 2018: 275].

Включение категории доверия в определение сущности понятия межнационального (межэтнического) согласия придает ему социально-экономическую, политическую, духовно-нравственную значимость и акцентирует внимание на текущей повестке. В современной России и ряде других стран доверия отчетливо не хватает, его необходимо намного больше. В докладе Всемирного экономического форума в Давосе о глобальных рисках в 2019 г. подчеркивается, что, если бы уровень доверия был таким же, как в Швеции, показатель роста дохода на душу населения составил бы в Великобритании 6\%, в Италии - $17 \%$, в Чехии $-29 \%$, в Мексике - 59\%, в России - $69 \% 1$.

Одна из сложных проблем состоит в том, что межнациональное (межэтническое) согласие на основе равноправия и справедливости в общественном сознании представляется как прообраз миропорядка, в котором происходит линейно-поступательное развитие. Тем не менее в современной действительности наиболее выразительна его цикличность. При этом либеральный межэтнический порядок перестает быть аксиомой, консенсус по поводу неких «общечеловеческих ценностей» постепенно отпадает.

Движение человеческого сознания от общих, по сути западных, ценностей совершается в направлении к более сложному миру множественных концепций. Человек мира сложностей шаг за шагом освобождается не только от природных, но и от социокультурных детерминаций. Заслуга авторского коллектива и его руководителя Л.М. Дробижевой заключается в том, что удалось выявить пластичность сознания граждан России, нацеленного на самореализацию в разных информационных средах и смысловых слоях культуры и религиозности.

В исследовании анализируется актуальная проблема консолидации местных сообществ в контексте миграционных процессов и выявляется зависимость интеграции мигрантов от консолидации местного сообщества. Авторы делают вывод, что «в тех регионах, где принимающее население более интегрировано, успешнее интегрируются и мигранты», и наоборот, «чем больше доля неинтегрированных местных жителей, тем больше доля неинтегрированных мигран-

1 Оверченко М. Мировой ком проблем. - Ведомости. 2019. 17 января 
тов». Поэтому в исследовании сформулированы рекомендации по разработке мер по консолидации локальных сообществ с целью интеграции в них мигрантов, где отмечается необходимость учитывать социально-политическую, экономическую и культурную специфику сообществ. Первоочередная задача властных структур - создание атмосферы согласия [Межнациональное согласие... 2018: 514], формирование соответствующей социокультурной среды, в которой не только комфортно, но и интересно жить.

Авторы подчеркивают, что проблемы возникающих противоречий местного населения и инокультурных приезжих связаны с неравенством возможностей в использовании ресурсов, доступе к высокооплачиваемым видам деятельности, в участии во власти, с отношением к достоинству людей различных национальностей и вероисповедания, удовлетворением их культурных и языковых потребностей [Межнациональное согласие... 2018: 504].

В развитии межнационального согласия выявлен новый этап, характеризующийся тем, что этническая принадлежность людей не является определяющим критерием в социальных взаимодействиях. При высоком уровне этнической идентификации (более чем у $90 \%$ респондентов) большинство людей разной национальности и вероисповедания не сталкиваются с проблемами в повседневной жизни [Межнациональное согласие... 2018: 505].

Новый этап в межнациональных отношениях характеризуется взаимодействием людей (групп людей) разных национальностей в трудовой, культурной и общественно-политической деятельности. Проявлением качественно нового этапа развитости межнационального согласия является аргументация базовых понятий, таких как российская, гражданская, политическая нации, гражданское единство, российская, гражданская, общероссийская идентичности и др., представленных в монографии и в Стратегии государственной национальной политики Российской Федерации на период до 2025 года1.

В монографии подчеркивается, что проявляющиеся в современных условиях в целом по России и регионам в частности неблагоприятные межэтнические установки, различия в поддержке мнения о равенстве народов представляют риск для межнационального согласия [Межнациональное согласие... 2018: 509].

Некоторые общественные формирования, отдельные социальные акторы в республиках предаются воспоминаниям о «былом величии», прежних инстинктах и том понимании суверенитета, легитимности, которые получили распространение в начале 1990-х гг. Возврат к периоду тех идей и комплексов - это откат в пропасть. «Риском для государственно- гражданской консолидации и согласия, - акцентируют внимание авторы монографии, - может явиться усиление этноконфессионального и национального размежевания в результате выраженной политики приоритета культуры и религии одного народа» [Межнациональное согласие... 2018: 512].

Многие российские социологические центры отмечают позитивный тренд в межэтнических отношениях: 78,5\% респондентов оценивают их положительно. Однако неблагоприятные межэтнические установки, враждебность к людям других национальностей проявляют 35-53\% населения [Межнациональное согласие... 2018: 504], возможности людей разных национальностей неравны, отмечают 40-57\% респондентов [Межнациональное согласие... 2018: 505]. В Москве $22 \%$ полагают, что межнациональные отношения напряженные, и $43 \%$ оценивают их как внешне спокойные, но внутренне напряженные. В

\footnotetext{
1 Указ Президента РФ от 06.12.2018 № 703 «О внесении изменений в Стратегию государственной национальной политики Российской Федерации на период до 2025 года, утвержденную Указом Президента РФ от 19 декабря 2012 года № 1666». Доступ: https://www.garant.ru/products/ipo/prime/ doc/72020010/ (проверено 24.05.2019).
} 
Московской обл. 58\% жителей ощущают межэтническую напряженность [Межнациональное согласие... 2018: 28]. Приведенные данные свидетельствуют о недостатке усилий по противостоянию деструктивным процессам.

Авторы неоднократно напоминают о потребности трансформации социальной среды, необходимости серьезных институциональных преобразований, а также о том, что образовательная и просветительная деятельность могут стать инструментами борьбы против распространения различных проявлений радикализма, ксенофобии в российском обществе [Межнациональное согласие... 2018: 513].

О конкретных процессах визуализации городского пространства в ракурсе межнационального согласия говорится в последней главе исследования. Речь идет о том, что символические памятники, например, Республики Башкортостан, связанные с образом этничности, башкирской героикой, частью русского населения воспринимаются конфликтно. Названия улиц в Уфе на русском и башкирском языках не воспринимает как справедливые часть татарского населения. Новые символические названия, связанные с общероссийской идентичностью, встречаются редко. Работа в этом отношении, подчеркивается в исследовании, - задача будущего [Межнациональное согласие... 2018: 515].

Всю систему межнационального согласия в общероссийском и региональном измерении исследовать довольно сложно. Но авторскому коллективу удалось осуществить крупное научное исследование актуальной темы, соединив множество философских и теоретических аргументов, эмпирических результатов применения социологической теории и размышлений относительно перспектив межнационального согласия в современной России. Все это представлено с глубоким пониманием сложности и значимости исследуемых процессов в сочетании с профессионализмом, строгостью и оригинальностью мысли. Исследование доказывает необходимость уделить особое внимание деловому участию государственных, гражданских институтов, бизнеса, науки в реализации принципов, целей, задач и основных направлений Стратегии государственной национальной политики Российской Федерации.

\section{Список литературы}

Межнациональное согласие в общероссийском и региональном измерении. Социокультурный и религиозный контексты: монография (отв. ред. Л.М. Дробижева). 2018. М.: ФНИСЦ РАН. 552 с.

\section{THE NATURE AND PRACTICE OF THE DEVELOPMENT OF INTERETHNIC CONCORD}

Abstract. The author considers the scientific work of the Federal Center of Theoretical and Applied Sociology of the Russian Academy of Sciences, completed under the supervision of Leokadiya Mikhaylovna Drobizheva. In the monograph, the authors analyze such topics, as the development and strengthening of interethnic concord, the development of the Russian ethnicity and general identity, the consolidation of the Russian society.

Keywords: interethnic concord, linguistic interaction, Russian nation, Russian and general identity, consolidation 